\title{
Identification of EDTA-Soluble Polysaccharides from Pea Epicotyl Cell Walls and Their Interaction with Xyloglucan
}

\author{
Elias A.-H. Baydoun ${ }^{1}$, Oula C. Mansour ${ }^{1}$, Sandra E. Rizk ${ }^{2}$, Christopher T. Brett ${ }^{3}$ \\ ${ }^{1}$ Department of Biology, American University of Beirut, Beirut, Lebanon; ${ }^{2}$ Department of Natural Sciences, Lebanese American \\ University, Beirut, Lebanon; ${ }^{3}$ Institute of Biomedical Life Sciences, University of Glasgow, Glasgow, United Kingdom. \\ Email: eliasbay@aub.edu.lb, oulamansour@hotmail.com, sandra.rizk@lau.edu.lb, c.t.brett@talk21.com
}

Received December $9^{\text {th }}, 2010$; revised March 23 ${ }^{\text {rd }}, 2011$; accepted March $31^{\text {st }}, 2011$.

\begin{abstract}
Nascent pectin and glucuronoxylan were prepared from membrane-bound enzymes obtained from pea epicotyls. They had previously been shown to exhibit a protein- and $p H$-dependent pattern of binding to cell wall ghosts and to xyloglucan extracted from cell walls prepared from pea epicotyls; maximum binding required a pH of 3-4, and the presence of cell wall proteins, namely assemblins. To determine whether wall polysaccharides deposited in cell walls behave in the same manner as nascent polymers, radioactively labeled EDTA-soluble polymers were prepared from newly-deposited pea epicotyl cell walls. Different enzyme treatments followed by column chromatography, in addition to complete acid hydrolysis followed by paper and thin layer chromatography, indicated the presence of pectin, together with smaller amounts of glucuronoxylan, in this EDTA-soluble extract. These radioactively labeled polysaccharides were found to bind to cell wall ghosts and to xyloglucan extracted from the second and third internodes of pea epicotyls cell walls in a pH-dependent manner, similar to the binding pattern obtained with nascent polymers. Maximum binding occurred at $\mathrm{pH} 3-4$, and also required the presence of protein.
\end{abstract}

Keywords: Assemblin, Cell Wall Assembly, Glucuronoxylan, Pectin, Pisum Sativum, Xyloglucan

\section{Introduction}

The plant cell wall contains cellulose microfibrils embedded in a non-crystalline matrix. Matrix polysaccharides are synthesized in the Golgi apparatus and transported in vesicles to the wall [1]. There, the newly synthesized matrix polysaccharides associate with each other and with newly synthesized cellulose to form the new innermost layer of the cell wall.

Xyloglucan, the principal hemicellulose of the primary cell walls of dicotyledonous plants, plays an essential role in cell wall elongation due to its strong association to cellulose microfibrils [2,3]. Nascent EDTA-soluble ${ }^{14} \mathrm{C}$-polysaccharides prepared from pea seedlings (Pisum sativum) consist of radioactively labeled pectins and glucuronarabinoxylans (GAX), with a significantly greater abundance of pectins [4]. These polysaccharides bound to xyloglucan in a pH-dependant manner, with the highest binding occurring at $\mathrm{pH} 3-4$, which corresponds to the $\mathrm{pH}$ of a growing wall. The binding decreased to almost zero at $\mathrm{pH} 6$ [5]. This binding pattern indicates a significant role in cell-wall assembly during deposition and cell wall extension during growth. Since pre-treatment of nascent GAX with protease greatly decreased the binding at acidic $\mathrm{pH}$ and abolished the $\mathrm{pH}$-dependant binding pattern, the protein attached to nascent GAX, named assemblin, appeared to have an essential role in the deposition of GAX into the cell wall [5]. However, cell wall polymers are synthesized in the Golgi apparatus and undergo several modifications prior to their excretion into the cell wall space [6]. The present study aims to determine whether newly-deposited polysaccharides extracted from preformed cell walls behave in the same manner as nascent polymers, with respect to their interaction with cell-wall ghosts and with xyloglucan.

\section{Materials and Methods}

\subsection{Plant Material}

Peas (Pisum sativum L.cv Meteor, obtained form Sharpes International, Sleaford, UK) were soaked overnight at 
room temperature and grown on damp vermiculite at $25^{\circ} \mathrm{C}$ in continuous darkness. For xyloglucan extraction, the peas were grown for 8 - 9 days. For the preparation of cell wall ghosts, nascent cell wall polymers and newly-deposited cell wall polymers, the growth period was 6 days.

\subsection{Preparation of Cell Wall Ghosts and Extraction of Xyloglucan}

A modification of the methods of Hayashi and Maclachlan (1984) and Ogawa et al. (1990) was used [7,8]. Third internodes $(50 \mathrm{~g})$ were harvested from 8-9-day-old peas and extracted three times with $70 \%(\mathrm{v} / \mathrm{v})$ ethanol $(150 \mathrm{ml}$, $\left.30 \mathrm{~min}, 70^{\circ} \mathrm{C}\right)$. The tissue was chopped with a razor blade, homogenized using a pestle and mortar in Tris- $\mathrm{HCl}$ buffer $(0.1 \mathrm{M}, \mathrm{pH} 7.0,75 \mathrm{ml})$, and centrifuged (8000 g, $10 \mathrm{~min})$. The cell wall pellets were extracted three times with EDTA buffer $(0.1 \mathrm{M}, \mathrm{pH} 7.0,75 \mathrm{ml}, 30$ min, $85^{\circ} \mathrm{C}$ ), and three times with $0.71 \mathrm{M} \mathrm{KOH} / 26 \mathrm{mM}$ $\mathrm{NaBH}_{4}\left(75 \mathrm{ml}, 1 \mathrm{~h}, 25^{\circ} \mathrm{C}\right)$ in a shaking incubator. Insoluble material (cell wall ghosts) was obtained by centrifugation (8000 g, $10 \mathrm{~min}$ ). To prepare xyloglucan, the cell wall ghosts were extracted twice with $4.3 \mathrm{M} \mathrm{KOH} / 26$ $\mathrm{mM} \mathrm{NaBH}_{4}\left(25 \mathrm{ml}, 4 \mathrm{~h}, 25^{\circ} \mathrm{C}\right)$ in the same incubator. The combined 4.3 M KOH-soluble fractions were neutralized with acetic acid. Ethanol was added $70 \%(\mathrm{v} / \mathrm{v})$, and xyloglucan allowed to precipitate overnight. The precipitated material was treated with salivary amylase $\left(24 \mathrm{~h}, 40^{\circ} \mathrm{C}\right)$ and protease (Type XIV, Sigma, $\left.24 \mathrm{~h}, 37^{\circ} \mathrm{C}\right)$. Xyloglucan content was determined by iodine-sodium sulphate method $[9,10]$.

\subsection{Preparation of Nascent EDTA-Soluble ${ }^{14} \mathrm{C}$-Polysaccharides}

The procedure for particulate enzyme preparation was similar to that of Waldron and Brett (1987) and Rizk et al. (2000) [5,11]. Epicotyls (6 - 9 cm long) were cut off, the hooks discarded and the remaining tissue cooled on ice. Subsequent operations were carried out at $0^{\circ} \mathrm{C}-4^{\circ} \mathrm{C}$. Epicotyls were homogenized using a pestle and mortar in Tris-Mes buffer (10 mM, pH 6.0). The homogenate was strained through two layers of muslin, and the filtrate centrifuged at 100,000 g for 30 minutes. The pellet was homogenized in cold homogenization buffer using a glass-Teflon tissue homogenizer, to obtain the particulate enzyme preparation, which was then incubated $\left(25^{\circ} \mathrm{C}, 4\right.$ h) with UDP-D-[U- $\left.{ }^{14} \mathrm{C}\right]$ glucuronic acid $(3.53 \mathrm{kBq}, 1.7$ $\mu \mathrm{M})$, UDP-xylose $(1 \mathrm{mM})$ and $\mathrm{MnCl}_{2}(10 \mathrm{mM})$. The reaction was terminated by adding $96 \%$ (v/v) ethanol. After centrifugation $(10,000 \mathrm{x} \mathrm{g}, 5 \mathrm{~min})$, particulate material was washed three times with $70 \%(\mathrm{v} / \mathrm{v})$ ethanol and extracted twice with $50 \mathrm{mM}$ EDTA/50 mM sodium phos- phate buffer $\left(\mathrm{pH} \mathrm{6.8)}\right.$ for $5 \mathrm{~min}$ at $100^{\circ} \mathrm{C}$. The combined EDTA/phosphate extracts were passed through a Sephadex G-100 column, eluted with water, and the excluded material was collected for binding experiments [5].

\subsection{Preparation of Newly-Deposited Cell Wall EDTA-Soluble ${ }^{14} \mathrm{C}$-Polysaccharides}

Newly-deposited cell wall ${ }^{14} \mathrm{C}$-polysaccharides were prepared by incubating pea epicotyls with $\left[{ }^{14} \mathrm{C}\right]$ sucrose ( $0.148 \mathrm{MBq}$ at the base of 10 epicotyls) for 24 hours. Cell wall pellets were obtained from these epicotyls as described above, and then extracted with boiling $50 \mathrm{mM}$ EDTA/50 mM sodium phosphate buffer ( $\mathrm{pH}$ 6.8) for 5 minutes. The EDTA-extracts obtained were passed through a column of Sephadex G-100 and eluted with water to remove low molecular weight products. The high molecular weight material which ran parallel to blue dextran was combined and used for analysis and binding assays to xyloglucan.

\subsection{Assay of Binding of ${ }^{14} \mathrm{C}$-Polysaccharides to Xyloglucan or to Cell Wall Ghosts}

Pea xyloglucans or cell wall ghosts (1 mg/incubation) were resuspended in $0.5 \mathrm{ml}$ incubation buffer $(10 \mathrm{mM}$ oxalate/10 $\mathrm{mM}$ phosphate, adjusted to the appropriate $\mathrm{pH}$ with $\mathrm{HCl}$ or $\mathrm{NaOH})$, mixed with $0.5 \mathrm{ml}{ }^{14} \mathrm{C}$-polysaccharides (generally $15-30 \mathrm{~Bq})$, incubated $\left(5 \mathrm{~min}, 25^{\circ} \mathrm{C}\right.$ and centrifuged ( $5 \mathrm{~min}, 10,000 \mathrm{x}$ g). Pellets were washed once with buffer of the appropriate $\mathrm{pH}(0.5 \mathrm{ml})$, centrifuged for $5 \mathrm{~min}$, resuspended in $0.4 \mathrm{ml}$ water and mixed with 4 ml Ultima-Flo AF (Packard Instrument Company, Meriden, Conn., USA) for liquid scintillation counting. All binding experiments were carried out in duplicate. Results are expressed as the mean \pm the difference between the experimental values and the means.

\subsection{Acid Hydrolysis}

Newly-deposited cell wall ${ }^{14} \mathrm{C}$-polysaccharides were acid hydrolyzed using trifluoroacetic acid $\left(2 \mathrm{M}, 120^{\circ} \mathrm{C}, 1 \mathrm{~h}\right)$. The hydrolysate was centrifuged at $10,000 \times \mathrm{g}$ and the supernatant was rotoevaporated to be analyzed by paper and thin layer chromatography.

\subsection{Chromatography}

Paper chromatography (PC) was performed using Whatman no. 3 paper, run in a solvent of ethyl acetate: pyridine: water $(8: 2: 1 \mathrm{v} / \mathrm{v})$ for 24 hours. Thin layer chromatography (TLC) was performed using silica coated plates and run in a solvent of butan-1-ol: ethyl acetate: water $(7: 1: 2 \mathrm{v} / \mathrm{v})$ for $18-22$ hours [12]. $1 \mathrm{~cm}$ strips (for the PC) and $0.5 \mathrm{~cm}$ strips (for the TLC) were cut from the chromatogram for scintillation counting. 


\subsection{Enzyme Treatments}

Radioactively labeled polysaccharides were subjected to several enzyme treatments prior to analysis by gel chromatography. Conditions used for enzyme treatments were as follows: Pectin lyase from Aspergillus japonicas (Sigma): 13 units in sodium acetate $(\mathrm{pH} 4)$ at $40^{\circ} \mathrm{C}$ for 16 $\mathrm{h}$; xylanase from Trichoderma viride (Megazyme, 40 units) and galactanase from Aspergillus niger (Megazyme, 15 units) in sodium acetate, $\mathrm{pH} 4.5$ at $40^{\circ} \mathrm{C}$ for $24 \mathrm{~h}$; endo-1, 4- $\beta$-glucanase (cellulase) from Trichoderma longibrachiatum (Megazyme): 5 units in sodium acetate, $\mathrm{pH} 5$ at $50^{\circ} \mathrm{C}$ for $16 \mathrm{~h}$. Reactions were stopped by boiling for 10 minutes.

To verify the role of proteins in the interaction between xyloglucan and newly-deposited EDTA-soluble 14C-polysaccharides, radioactively labeled polysaccharides were treated with 5 units of proteinase $\mathrm{K}$ (from Tritirachium album, Sigma) in Mes, $(\mathrm{pH} \mathrm{7})$ at $37^{\circ} \mathrm{C}$ for $16 \mathrm{~h}$ prior to performing binding assays. Enzyme treatment was terminated by boiling for 10 minutes.

\section{Results}

\subsection{Identification of EDTA-Soluble \\ ${ }^{14}$ C-Polysaccharides Prepared from Pea \\ Stems Incubated with $\left[{ }^{14} \mathrm{C}\right]$ Sucrose}

To determine the nature of the newly-deposited high molecular weight EDTA-soluble ${ }^{14} \mathrm{C}$-polysaccharides, prepared from pea stems incubated with $\left[{ }^{14} \mathrm{C}\right]$ sucrose, they were first subjected to complete acid hydrolysis $(2 \mathrm{~N}$
TFA, $120^{\circ} \mathrm{C}, 1 \mathrm{~h}$ ) followed by PC and TLC. Paper chromatography showed the presence of radioactively labeled glucose, with smaller amounts of galactose and minor amounts of mannose, arabinose, fucose and xylose (Figure 1). However uronic acids did not migrate under the experimental conditions used for the paper chromatography, so the acid hydrolysate was analyzed by TLC using silica-coated plates. This indicated the presence of both galacturonic acid (present in pectins) and glucuronic acid (present in xylans), in a ratio of $2.5: 1$, indicating the greater abundance of pectins than xylans in the extract (Figure 2).

To confirm this, the EDTA-soluble ${ }^{14} \mathrm{C}$-polysaccharides were subjected to several enzyme treatments and the products were analyzed by column chromatography. Upon treatment with amylase, the amount of high molecular weight material did not decrease significantly, indicating that the presence of glucose revealed by PC analysis is not due to the presence of starch (Figure 3). Upon treatment with pectin lyase and passage through Biogel P2, the amount of high molecular weight material only decreased slightly (Figure 4); this is probably because pectin lyase only acts on certain bonds within the large pectin molecules, producing chains that are large enough to be excluded from Biogel P2. When using a Biogel P10 column, which has a higher exclusion limit, over $50 \%$ of the high molecular weight material was shown to be degraded (Figure 5). The radioactively labeled polymers also contain a significant amount of xylans, as indicated by the analysis of xylanase treated ex-

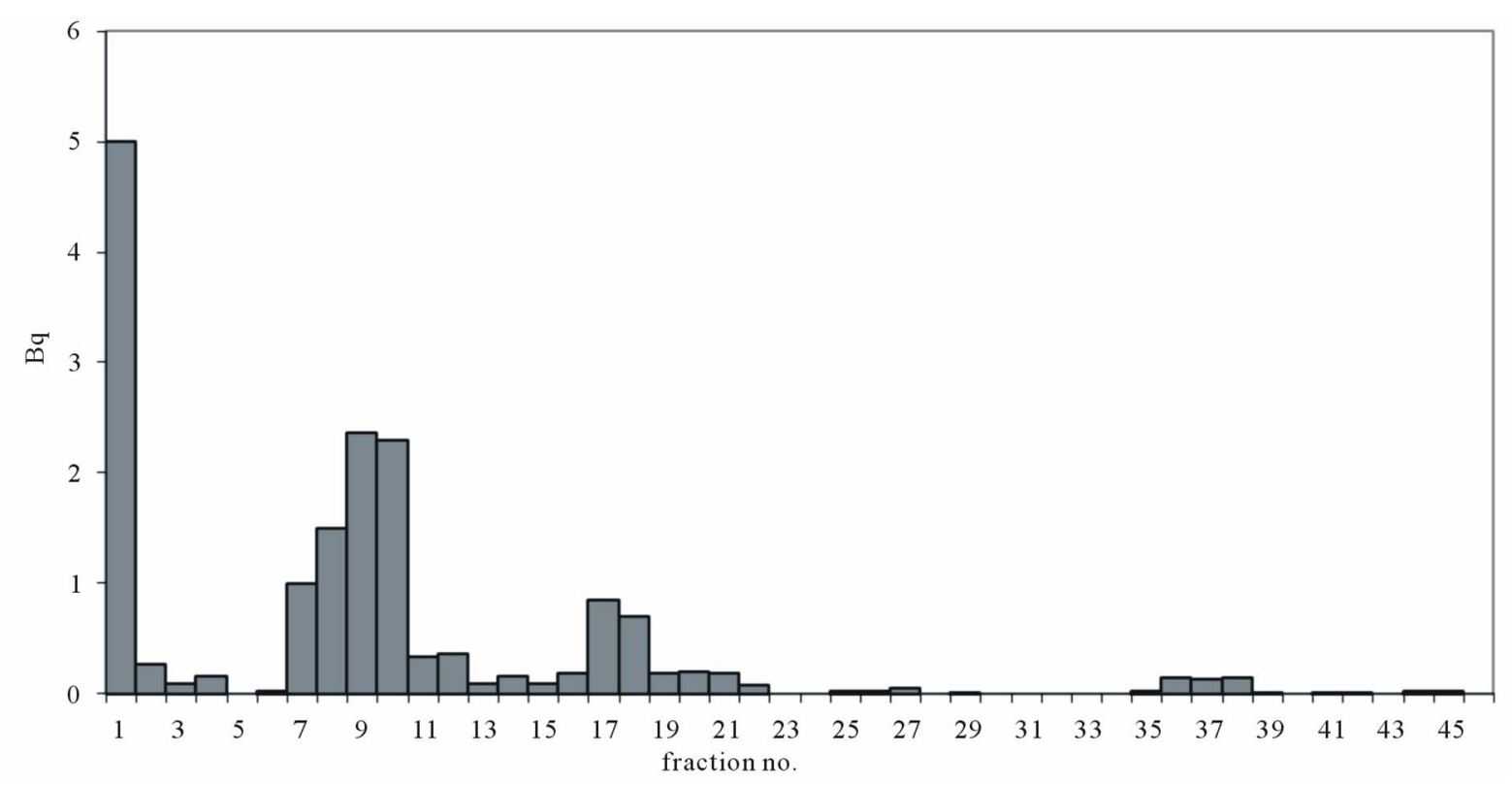

Figure 1. PC of total hydrolysate of cell wall EDTA-soluble polysaccharides. Marker sugars: galactose (7 - 8), glucose (9 - 10), mannose (12 - 14), arabinose (16 - 18), fucose + xylose (20 - 22), rhamnose (36 - 38). 


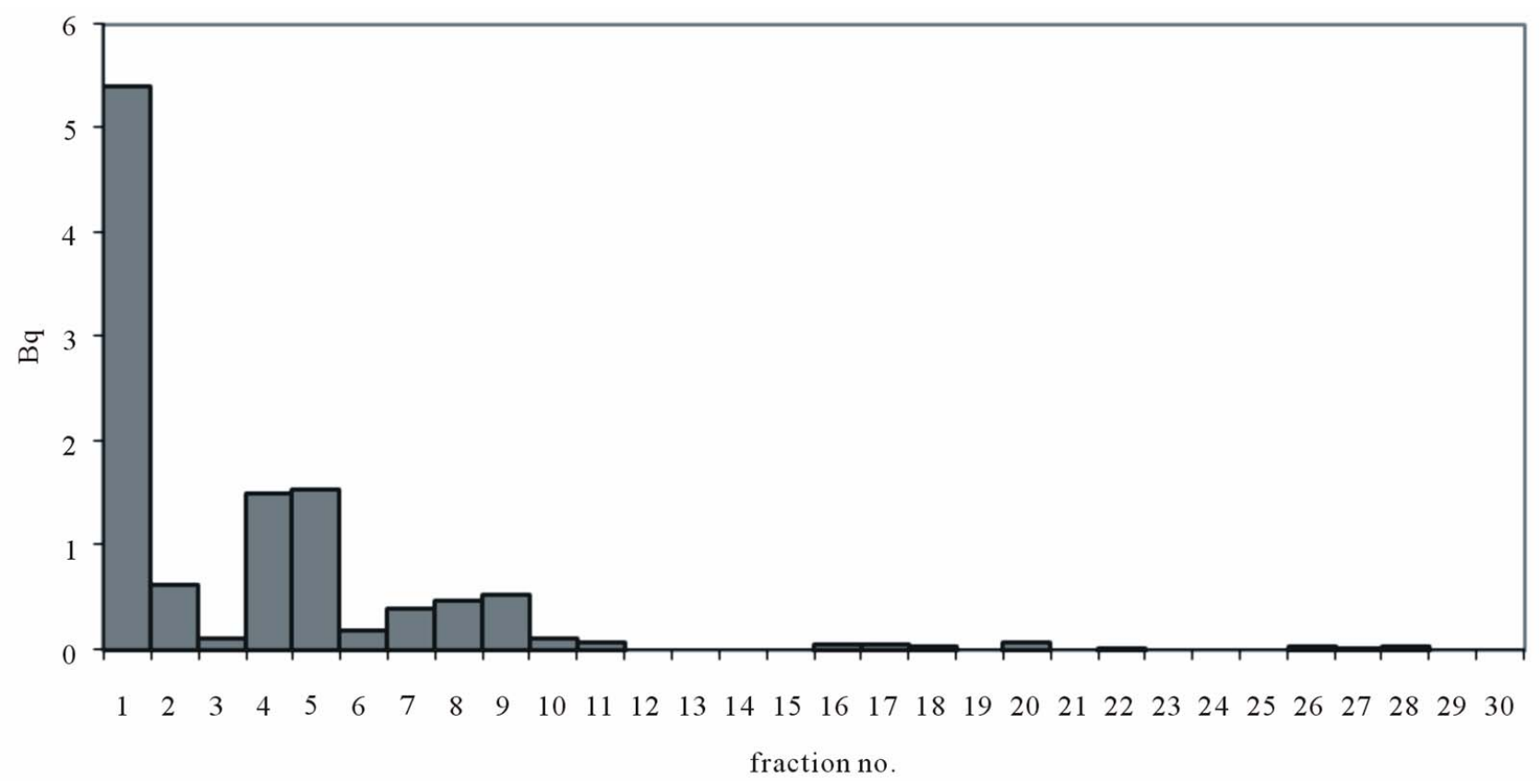

Figure 2. TLC of total hydrolysate of cell wall EDTA-soluble polysaccharides. Marker sugars: galacturonic acid (4 - 5), glucuronic acid (7 - 9).

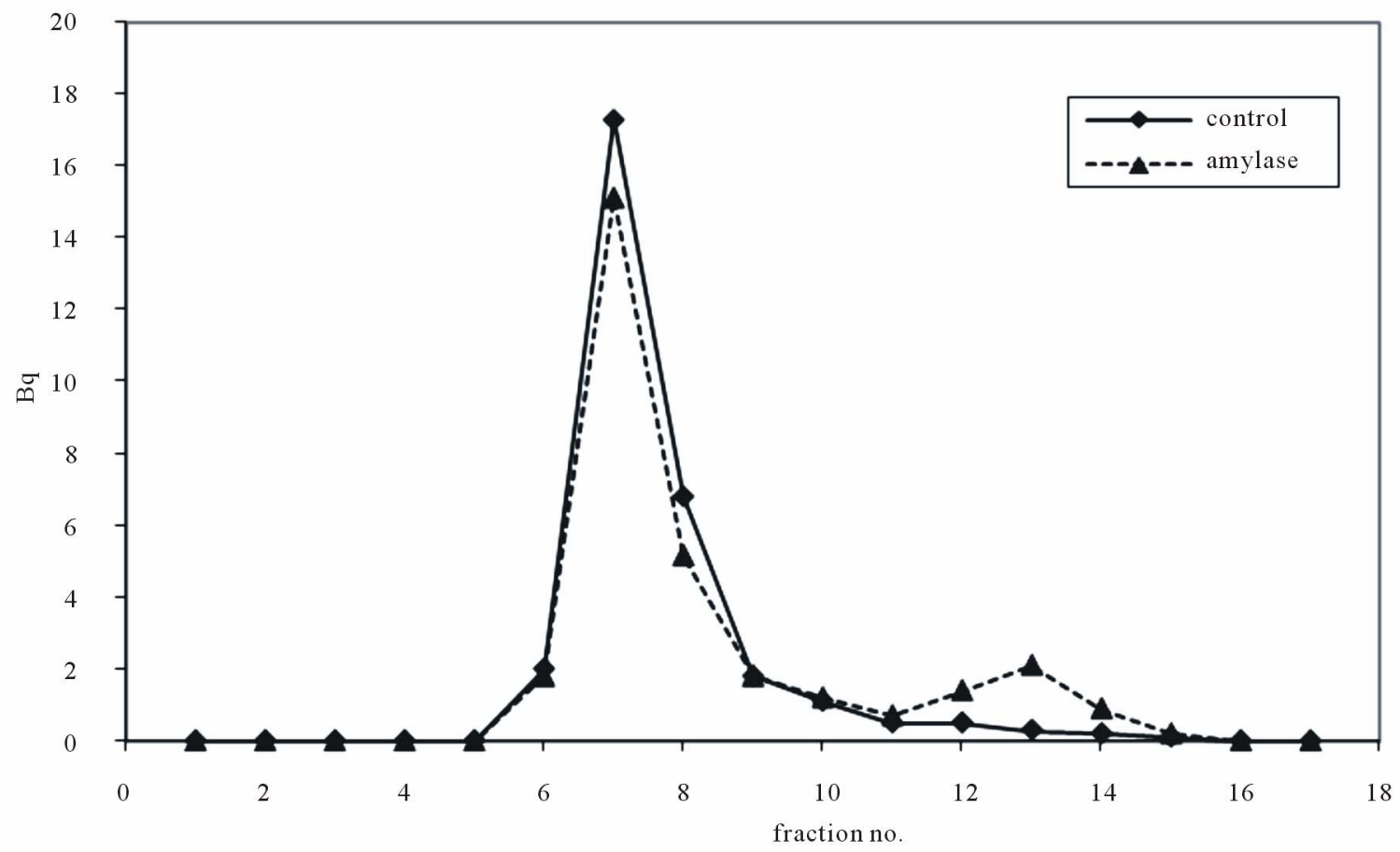

Figure 3. Gel filtration on Biogel P2 of amylase products of cell wall EDTA-soluble polysaccharides. $\mathrm{BD}\left(7\right.$ - 8), $\mathrm{CoCl}_{2}(14$ - 16).

tracts that were passed through Biogel P2 and P10 col-umns: in both cases, $35 \%-40 \%$ of the radioactivity was collected as low molecular weight products. The remaining polymers that were stable to pectin lyase and xylanase action were broken down by galactanase and $\beta(1-4)$ glucanase, indicating the presence of minor amounts of galactans and xyloglucan in the extracts (Figure 6). The presence of xyloglucan in the EDTAsoluble fraction may be due to covalent bonding to pectin, resulting in its co-extraction with pectin [13]. 


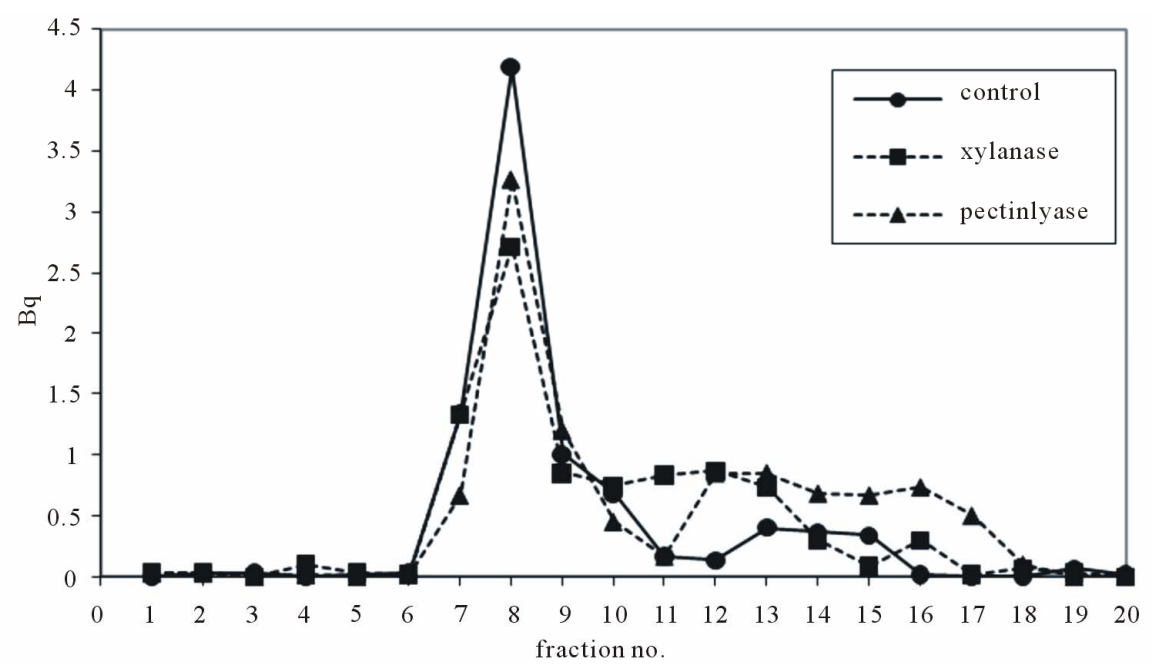

Figure 4. Gel filtration on Biogel P2 of xylanase and pectin lyase products of cell wall EDTA-soluble polysaccharides. BD (6 9), $\mathrm{CoCl}_{2}(15$ - 19).

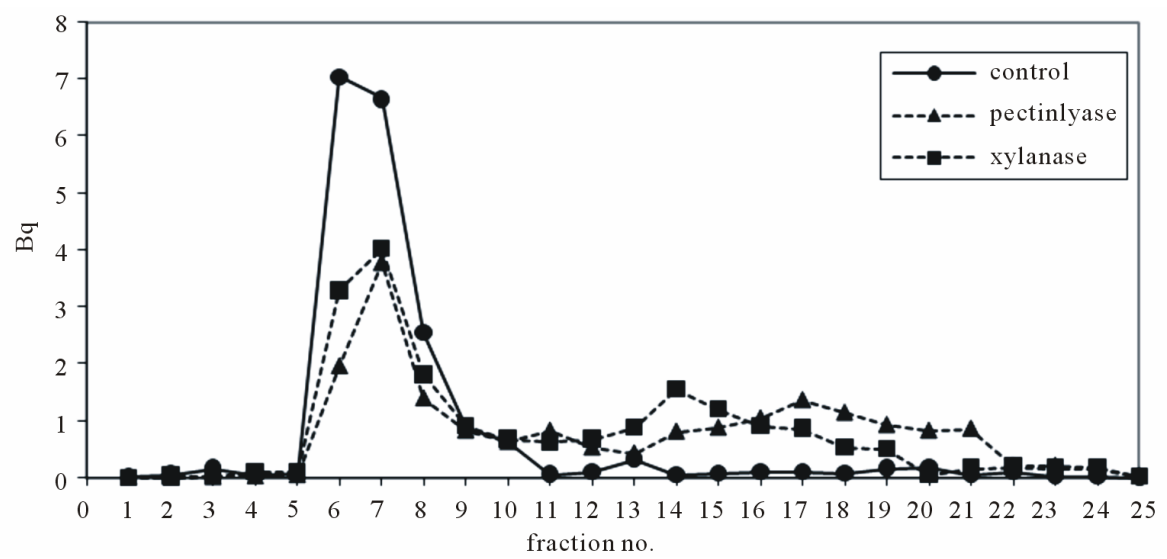

Figure 5. Gel filtration on Biogel P10 of xylanase and pectin lyase products of cell wall EDTA-soluble polysaccharides. BD (6 - 8), $\mathrm{CoCl}_{2}(14$ - 19).

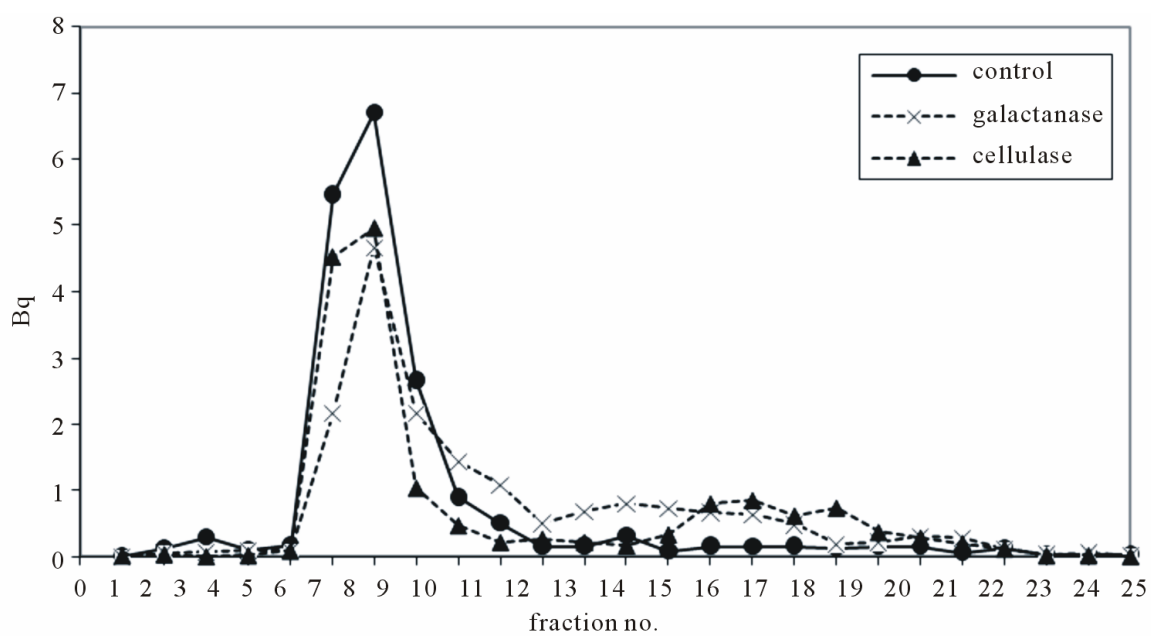

Figure 6. Gel filtration on Biogel P10 of cellulose and galactanase products of cell wall EDTA-soluble polysaccharides. BD (6 8), $\mathrm{CoCl}_{2}$ (15 - 19). 


\subsection{Binding of Newly-Deposited EDTA-Soluble ${ }^{14}$ C-Poly- Saccharides and Nascent EDTA-Soluble ${ }^{14} \mathrm{C}$-Polysaccharides to Cell Wall Ghosts.}

Samples of the newly-deposited EDTA-soluble ${ }^{14} \mathrm{C}$ polysaccharides were incubated with cell-wall "ghosts", i.e. cell wall fragments which had been pre-extracted with EDTA to remove pectin. Samples of nascent EDTA-soluble ${ }^{14} \mathrm{C}$-polysaccharides (prepared by incubating a Golgi-rich membrane fraction with UDP-D-[U- $\left.{ }^{14} \mathrm{C}\right]$ glucuronic acid) were incubated with cell-wall ghosts in the same way. Results obtained showed that, over the $\mathrm{pH}$ range 3 to 6, binding of newly-deposited EDTA-soluble ${ }^{14} \mathrm{C}$-polysaccharides to cell-wall ghosts occurred maximally at $\mathrm{pH} 3$, which corresponds to the $\mathrm{pH}$ of a growing cell wall $[14,15]$, and decreased with increasing $\mathrm{pH}$ until, at $\mathrm{pH} 6$, it was only $25 \%$ of the value at $\mathrm{pH} 3$ (Figure 7). The pattern of binding of nascent EDTA-soluble ${ }^{14} \mathrm{C}$ polysaccharides to cell-wall ghosts was almost the same, except that the residual binding at $\mathrm{pH} 6$ was even lower (Figure 7).

\subsection{Binding of Newly-Deposited and Nascent EDTA- Soluble ${ }^{14} \mathrm{C}$-Polysaccharides to Xyloglucan.}

Xyloglucan was extracted and purified from the third internode of 10-day old pea stems. The binding of newly-deposited and nascent EDTA-soluble ${ }^{14} \mathrm{C}$-polysaccharides to this xyloglucan over the $\mathrm{pH}$ range 3 to 6 was now investigated. The binding patterns obtained (Figure 8) were very similar both to each other and to the patterns of binding to cell-wall ghosts (Figure 7). For nascent EDTA-soluble ${ }^{14} \mathrm{C}$-polysaccharides, this confirms the pattern of binding to xyloglucan reported by Rizk et al. (2000) [5].

Effect of protease treatment of newly-deposited EDTAsoluble ${ }^{14} \mathrm{C}$-polysaccharides on binding to xyloglucan.

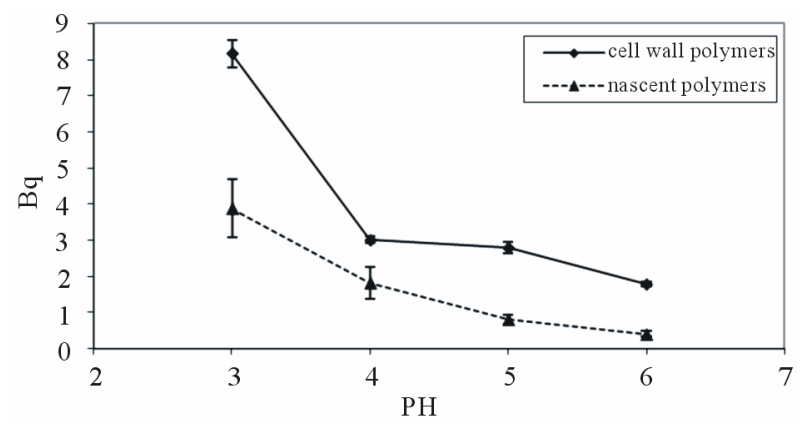

Figure 7. Effect of pH on binding of nascent and cell wall EDTA-soluble polymers to cell wall ghosts.

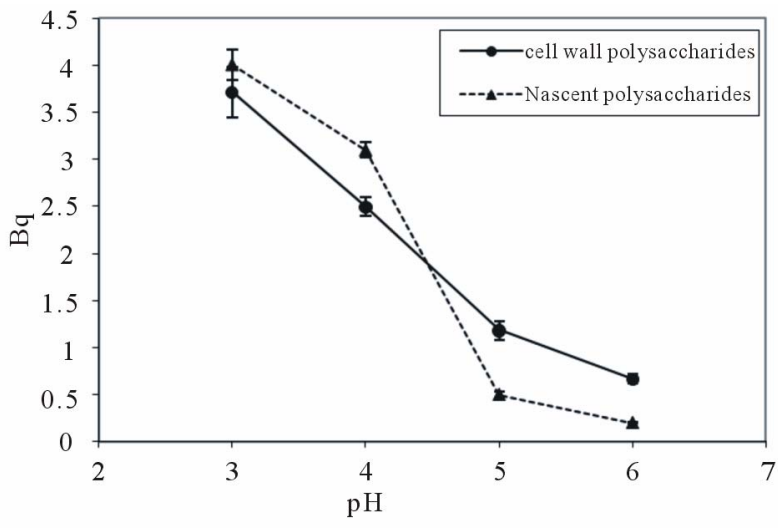

Figure 8. Effect of pH on binding of nascent and cell wall EDTA-soluble polysaccharides to xyloglucan.

Finally, to check whether newly-deposited EDTAsoluble ${ }^{14} \mathrm{C}$-polysaccharides are still linked to protein after deposition in the cell wall [16], and to verify the role of this protein in the binding to xyloglucan, the newly-deposited EDTA-soluble ${ }^{14} \mathrm{C}$-polysaccharides were subjected to protease treatment prior to performing the binding assays over the $\mathrm{pH}$ range 3 to 6 . The protease treatment greatly decreased the binding at $\mathrm{pH} 3$ and at higher $\mathrm{pH}$ values (Figure 9). This effect of protease is very similar to that already reported for the effect of protease on the binding of nascent EDTA-soluble ${ }^{14} \mathrm{C}$-polysaccharides to xyloglucan [5]. The result confirms thatprotein is required for the binding of newly-deposited EDTA-soluble wall polysaccharides to xyloglucan after deposition in the cell wall.

\section{Discussion}

Nascent GAX was previously reported to bind to hemicellulose from pea epicotyls in a $\mathrm{pH}-$-dependent manner, with the highest binding at $\mathrm{pH} 3.5-4.0$; the binding was thought to occur via non-covalent bonds [4]. Further

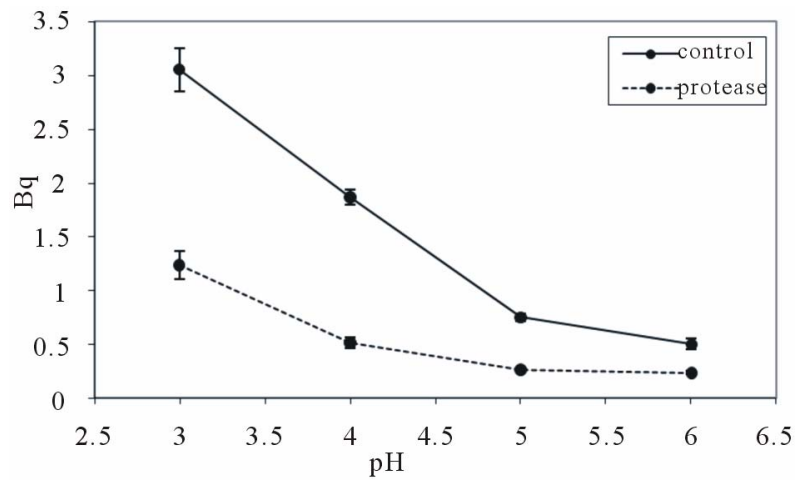

Figure 9. Effect of protease pre-treatment of cell wall EDTAsoluble polysaccharides on the binding to xylogucan. 
studies indicated that a similar binding pattern occurs between nascent GAX and pectin to xyloglucan extracted from the third internodes of pea epicotyls, and that the binding requires the presence of proteins named assemblins [5]. The association between the polymers would probably not occur in Golgi vesicles prior to their arrival at the plasma membrane, since the $\mathrm{pH}$ within Golgi vesicles is thought to be close to neutrality. The present investigation aimed at investigating the interaction between xyloglucan and polymers that have already been deposited into the wall. The results obtained confirm that the binding pattern between xyloglucan and EDTA-soluble polysaccharides that have been extracted from the wall, is similar to that reported between xyloglucan and nascent EDTA-soluble polysaccharides obtained from Golgi membranes [5]. To identify these polysaccharides, different enzyme treatments followed by gel filtration were performed, in addition to acid hydrolysis followed by chromatography of the hydrlolysate. The results indicated the newly-deposited polysaccharides consisted of pectin, probably with some xyloglucan attached, and smaller amounts of glucuronoxylan. These polysaccharides were found to bind to xyloglucan in a $\mathrm{pH}$-dependent manner, whereby $\mathrm{pH} 3$ gave the highest binding over the $\mathrm{pH}$ range tested, which is similar to that reported by Rizk et al., 2000. This $\mathrm{pH}$ corresponds to that of a cell wall undergoing growth, and lower $\mathrm{pH}$ values were not tested because they would be of doubtful physiological significance. The binding greatly decreased when the polysaccharides were subjected to protease treatment prior to performing the binding assay, confirming the presence of proteins associated with these polymers after their deposition into the wall.

This protein- and $\mathrm{pH}$-dependent binding suggests a functional interaction with the mechanisms that control growth. In pea epicotyls, the $\mathrm{pH}$ of the wall decreases to 3 when growth is initiated [14]. Rapid growth may require strong interactions between matrix polymers in order to maintain the cohesion of the wall. In addition, pectin and GAX molecules present in the cell wall may compete with cellulose for binding to xyloglucan at an acidic $\mathrm{pH}$, interfering with the strong xylogluca$\mathrm{n}$-cellulose binding, and hence rendering the cell wall more extensible to allow rapid growth.

\section{REFERENCES}

[1] A. Staehelin and I. Moore, "The Plant Golgi Apparatus: Structure, Functional Organization and Trafficking Mechanisms," Annual Review of Plant Physiology and Plant Molecular Biology, Vol. 46, 1995, pp. 261-288. doi:10.1146/annurev.pp.46.060195.001401

[2] S. C. Fry, "Cellulases, Hemicelluloses and Auxinstimu- lated Growth: A Possible Relationship," Plant Physiology, Vol. 75, No. 4, 1989, pp. 532-536. doi:10.1111/j.1399-3054.1989.tb05620.x

[3] T. Hayashi, K. Ogawa and Y. Mitsuishi, "Characterization of the Adsorption of Xyloglucan to Cellulose," Plant and Cell Physiology, Vol. 35, No. 8, 1994, pp. 11991205.

[4] C. T. Brett, S. A. Healy, M. S. McDonald, C. Macgregor and E. Baydoun, "Binding of Nascent Glucuronoxylan to the Cell Walls of Pea Seedlings," International Journal of Biological Macromolecules, Vol. 21, No. 1-2, 1997, pp. 169-173. doi:10.1016/S0141-8130(97)00057-3

[5] S. Rizk, M. R. Abdel, E. Baydoun and C. T. Brett, "Protein- and pH-Dependent Binding of Nascent Glucuronarabinoxylan to Xyloglucan in Pea," Planta, Vol. 211, 2000, pp. 423-429. doi:10.1007/s004250000303

[6] W. D. Reiter, "Biosynthesis and Properties of the Plant Cell Wall," Current Opinion in Plant Biology, Vol. 5, No. 6, 2002, pp. 536-542. doi:10.1016/S1369-5266(02)00306-0

[7] T. Hayashi and G. Maclachlan, "Pea Xyloglucan and Cellulose. I. Macromolecular Organization," Plant Physiology, Vol. 75, 1984, pp. 596-604. doi:10.1104/pp.75.3.596

[8] K. Ogawa, T. Hayashi and K. Okamura, "Conformational Analysis of Xyloglucan," International Journal of Biological Macromolecules, Vol. 12, No. 3, 1990, pp. 218222. doi:10.1016/0141-8130(90)90036-A

[9] P. Kooiman, "A Method for Determination of Amyloid in Plant Seeds," Recueil des Travaux Chimiques des Pays-Bas et de la Belgique, Vol. 79, 1960, pp. 675-678.

[10] T. Hayashi, Y. Kato and K. Matsuda, "Xyloglucan from Suspension-Cultured Soybean Cells," Plant and Cell Physiology, Vol. 21, No. 8, 1980, pp. 1405-1418.

[11] K. W. Waldron and C. T. Brett, "Subcellular Localization of a Glucuronyltransferase Involved in Glucuronoxylan Biosynthesis in Pea (Pisum Sativum) Epicotyls," Plant Science, Vol. 49, No. 1, 1986, pp. 1-8. doi:10.1016/0168-9452(87)90013-6

[12] S. C. Fry, "The Growing Plant Cell Wall: Chemical and Metabolic Analysis," John Wiley and Sons, New York, 1988.

[13] C. M. Cumming, H. D. Rizkallah, K. McKendrick, R. M. Abdel-Massih, E. Baydoun and C. T. Brett, "Biosynthesis and Cell-Wall Deposition of a Pectin-Xyloglucan Complex in Pea," Planta, Vol. 222, 2005, pp. 546-555. doi:10.1007/s00425-005-1560-2

[14] R. E. Cleland, G. Buckley, S. Nowbar, N. M. Lew, C. Stienmetz, M. L. Evans and D. L. Rayle, "The pH Profile for Acid-Induced Elongation of Coleoptile and Epicotyl Sections Is Consistent with the Acid-Growth Theory," Planta, Vol. 186, No. 1, 1991, pp. 70-74. doi:10.1007/BF00201499

[15] U. Kutschera, "The Current Status of the Acid Growth Theory," New Phytologist, Vol. 126, No. 4, 1994, pp. 549-569. doi:10.1111/j.1469-8137.1994.tb02951.x 
[16] A. Baydoun, M. C. Hobbs, M. H. P. Delarge, M. J. Farmer, K. W. Waldron and C. T. Brett, "Formation of Glucuronoxylan Linked to Protein in Plant Golgi and Plasma Mem- branes," Biochemical Society Transactions, Vol. 19, No. 3, 1991, p. 250S. 